\title{
Modelling Soil Erosion and Sedimentation in the Oued Haricha Sub-Basin (Tahaddart Watershed, Western Rif, Morocco): Risk Assessment
}

\author{
Mounia Tahiri' ${ }^{1}$, Hassan Tabyaoui ${ }^{2}$, Abdelfatah Tahiri ${ }^{3 *}$, Hassan El Hadi ${ }^{1}$, \\ Fatima El Hammichi'2, Mohammed Achab ${ }^{3}$ \\ ${ }^{1}$ Applied Geology, Geomatic \& Environment Laboratory Sciences, Faculty of Ben Msik, Hassan II University \\ of Casablanca, Casablanca, Morocco \\ ${ }^{2}$ Natural Resources and Environment Laboratory, Polydisciplinary Faculty of Taza, Sidi Mohamed Ben \\ Abdellah University, Fez, Morocco \\ ${ }^{3}$ Geology and Remote Sensing Laboratory, URAC46, Mohammed V University of Rabat, Scientific Institute, \\ Morocco \\ Email: *abdelfatahtahiri@gmail.com
}

Received 9 December 2015; accepted 15 January 2016; published 18 January 2016

Copyright (C) 2016 by authors and Scientific Research Publishing Inc.

This work is licensed under the Creative Commons Attribution International License (CC BY).

http://creativecommons.org/licenses/by/4.0/

(c) (i) Open Access

\section{Abstract}

This study evaluates the annual loss of soil in the sub-basin of Oued Haricha (Tahaddart basin, Western Rif, NW Morocco). The integration of revised (RUSLE) and modified (MUSLE) soil loss empirical equations of Wischmeier and Smith in combination with GIS permits the modelling of soil erosion at the scale of parcels. The characteristics of precipitation and runoff, the soil properties, the culture system and the current working practices of soil in the sub-basin of the Oued Haricha are collected from local data. The digital terrain model is used to generate topographic factors. The combination of different RUSLE factors shows that the annual soil is $62.72 \mathrm{t} / \mathrm{ha} / \mathrm{year}$ and corresponds to an average level of risk. The total losses calculated by MUSLE method are valued at $221,468 \mathrm{t} /$ year. The rates of loss due to linear erosion are $82,652 \mathrm{t} /$ year. These soil losses represent $20.33 \%$ of the total losses, and confirm that the losses on the slopes outweigh the losses due to the river system. Sedimentation module shows that the areas of high erosion (greater than $200 \mathrm{t} / \mathrm{ha}$ /year) are concentrated in the reliefs with average and high slope and occupy $38 \%$ of the total area. The deposition areas occupy the centre of sub-basin and constitute $9.12 \%$ of the total area. These deposits were concentrated on the edges of major rivers and the outlet of the sub-basin and contributed to siltation of the April 9, 1947 dam.

"Corresponding author.

How to cite this paper: Tahiri, M., Tabyaoui, H., Tahiri, A., El Hadi, H., El Hammichi, F. and Achab, M. (2016) Modelling Soil Erosion and Sedimentation in the Oued Haricha Sub-Basin (Tahaddart Watershed, Western Rif, Morocco): Risk Assessment. Journal of Geoscience and Environment Protection, 4, 107-119. http://dx.doi.org/10.4236/gep.2016.41013 


\section{Keywords}

\section{Soil Erosion, Deposition, Oued Haricha, NW-Rif, Morocco}

\section{Introduction}

Research conducted over the past forty years have shown the value of the estimated soil loss using the accrual rate in downstream dams, reservoirs and other deposit areas [1]. Recent studies have largely involved the use of distributed and empirical models. These models consider the spatial heterogeneity of the use of watershed lands, soil properties, topography and spatial interaction processes of erosion, transport and deposition of sediments. The validation of these models is generally limited to the comparison of the predicted and measured outputs from the watershed.

The results of soil loss computations vary from one basin to another. This difference is due to variations in the physical characteristics of each basin, including the power of erosion by rain, the intrinsic susceptibility of soils to erosion, as well as the combined effect of the tilt and angle length of the slope. Human activities also play a role in sofar as natural vegetation is disturbed, and practices that control erosion can affect sediment loss.

Empirical models are integrated approaches permitting the soil erosion modelling in watersheds in response to changes in land use. The nature and extent of watershed degradation and erosion can be provided to the past, present and future conditions.

To link the eroding factors between them and quantify soil loss, several equations are developed (USLE: Universal Soil Loss Equation of Wischmeier and Smith [2]; WEPP: Water Erosion Prediction Project [3]; SWAT: Soil and Water Assessment Tool [4]; EUROSEM: European Soil Erosion Model [5]). Several computer models have subsequently emerged; some of them are based on the Universal Soil Loss Equation (USLE) and its modified (MUSLE) and revised (RUSLE) versions. GIS software is getting ready to assess these equations and thus mapping the rate of erosion and soil loss at the parcels' scale from the upstream of the basins.

This paper complements the studies already undertaken in northern Tahaddart watershed (Oued Sania subbasin) in where the soil loss is quantified [6]-[9]. The objective is to produce modelled estimates of soil loss from empirical models for the Oued Haricha sub-basin. The applied models are based on the Universal Soil Loss Equation (USLE Universal Soil Loss Equation) with its revised (RUSLE) and modified (MUSLE) versions. These are supplemented by the deposition module for calculating the balance sheet of erosion.

\section{The Study Area}

The Oued Haricha sub-basin is part of the Tahaddart watershed (Western Rif, NW Morocco). It has an area of $221.82 \mathrm{~km}^{2}$ and is characterized by an altitudinal variation ranging from $10 \mathrm{~m}$ at the outlet (dam of 9 April 1947) to $941 \mathrm{~m}$ at the top of the most prominent reliefs situated in the east and in the south (Figure 1). The region has a Mediterranean climate tempered by Atlantic influences, with an average annual rainfall of $689.4 \mathrm{~mm}$ (meteorological station of dam April 9, 1947) for the periods from 1970 to 2015. The 1995-1996 hydrological year is the wettest year with $1279.5 \mathrm{~mm}$ precipitation, while 1994-1995 is the driest year with precipitation of 237.2 $\mathrm{mm}$ (Figure 2). December is the wettest month $(140 \mathrm{~mm})$ while July is the driest month $(0.4 \mathrm{~mm})$. The average monthly temperature recorded shows that August is the hottest month $\left(\mathrm{T}=23.9^{\circ} \mathrm{C}\right)$ and January is the coldest one $\left(12.5^{\circ} \mathrm{C}\right)$.

The Oued Haricha sub-basin has an elongated shape. Its compactness index of Gravelius Kc is equal to 1.44. It is drained by Oued Haricha over a length of $24.63 \mathrm{~km}$. This river takes its birth in the southeast of the sub-basin and ends to the west by the dam of April 9, 1947 (Figure 3). The time of concentration Tc, calculated using the most widespread empirical formulas in Morocco (Formulas of Turazza, Ventura, Kripich, Giandotti, California and Passini) gives an average of 2.70 hrs. This time is relatively long, which will cause a slow gathering of water towards the outlet.

The soils type in the sub-basin of Oued Haricha studied by [10] [11], classified according to the CPCS classification system [12] are generally the low developed soils (25.66\% of the total surface), lithosols (14.91\%), vertisols (32.48\%), brown soils (19.22\%), hydromorphic soils (2.69\%) and iron sesquioxides soils (2, 34\%). The natural vegetation consists of matorral moderately dense and degraded in the hills ( $16 \%$ of the total area). The 


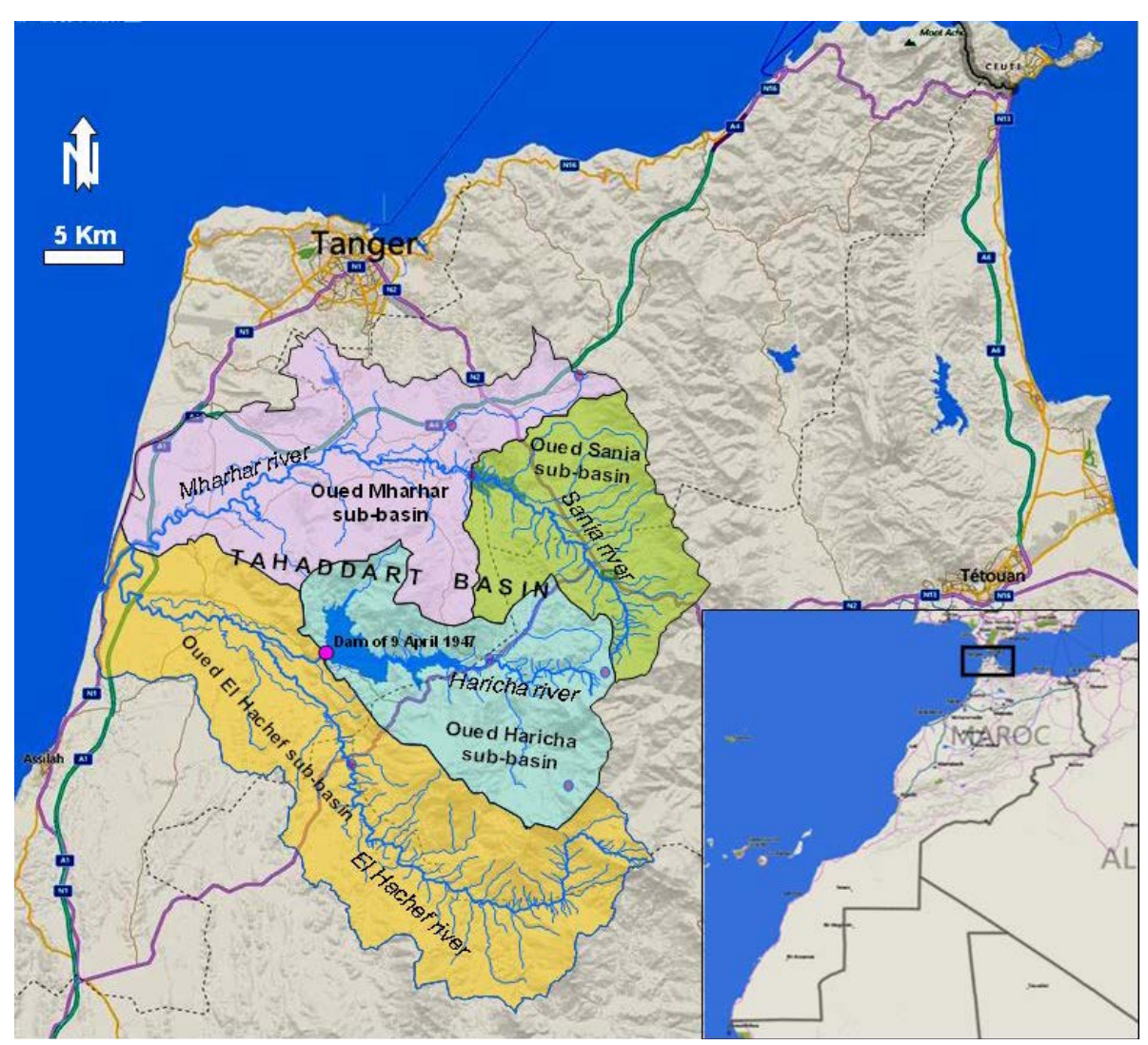

Figure 1. Situation of Oued Haricha sub-basin in Tahaddart watershed in NW of Morocco.

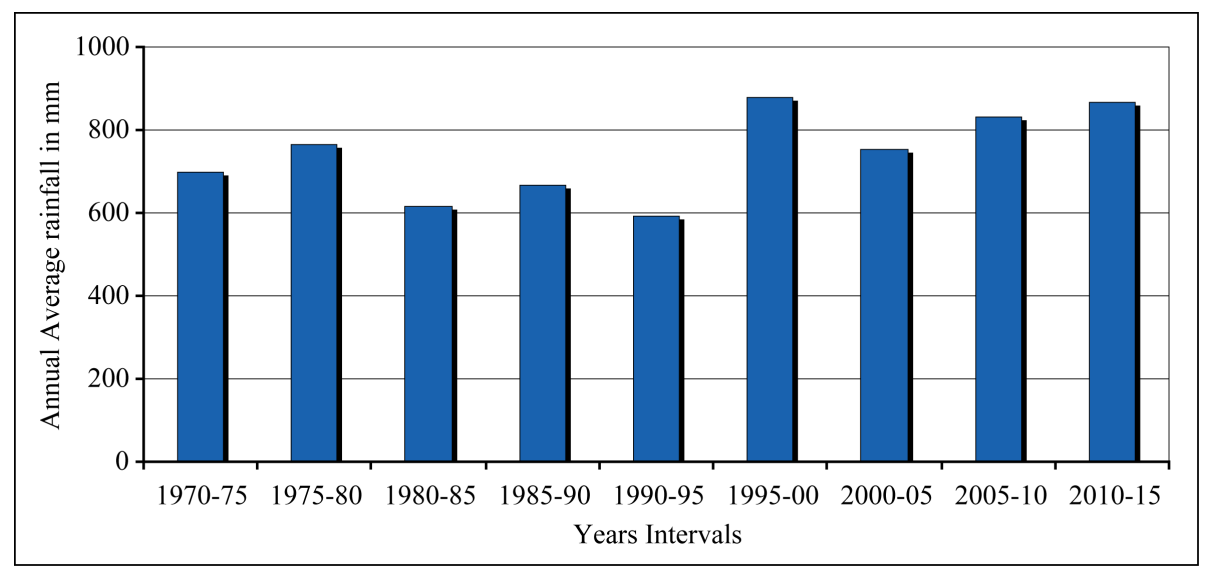

Figure 2. Annual rainfall in the meteorological station April 9, 1947 during the period 19702015.

Aleppo pine mixed or not with cork oak and Eucalyptus plantations dominate especially at the breakwater of the dam. These forests constitute $52 \%$ of the total area. Ligneous vegetations dominate the high and low hills of the sub-basin (5\%). The valley floor is occupied by cereal (18\% of the total area).

\section{Factors of Erosion}

The potential for erosion can be calculated after identification of individual soil factors values. The following section briefly describes each RUSLE and MUSLE factor and lists inputs for the time-invariant (average annual values) module. 


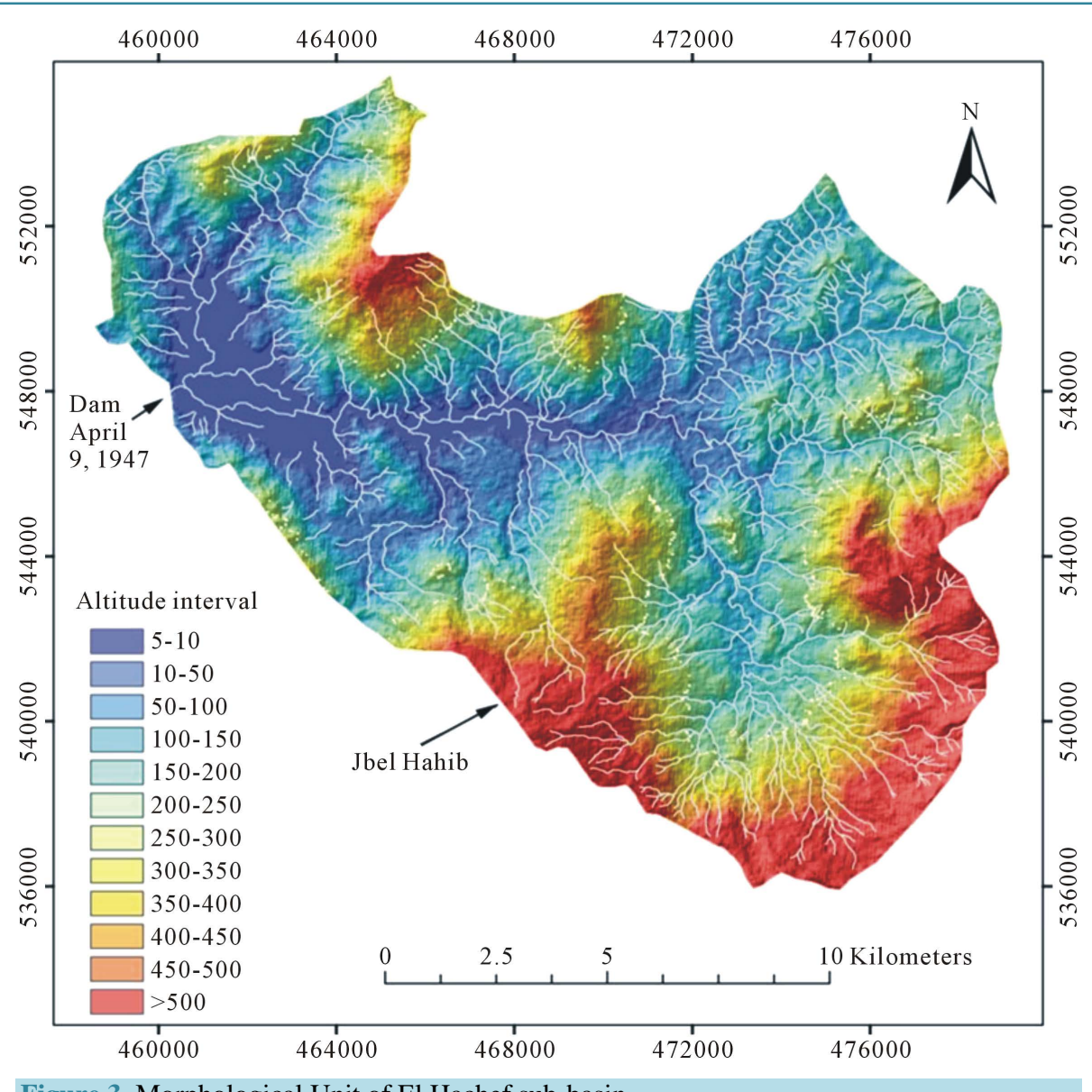

Figure 3. Morphological Unit of El Hachef sub-basin.

\subsection{Rainfall Erosivity Factor (R)}

The $\mathrm{R}$ factor for a given location is derived from precipitation records, placed on an iso-erodent map. Local $\mathrm{R}$ values are calculated directly from the equation of Arnoldus [13] (Equation (1)), for the meteorological stations of Ibn Battuta, Dar Chaoui, Jbel Hbib, Béni Harchane, Skarich and April 9, 1947 (Figure 1). The rainfall data series used are especially monthly and yearly average.

$$
\mathrm{R}=1.753 \times 10((1.5 \log \Sigma(\mathrm{Pi} 2) / \mathrm{P})-0.8188)
$$

where:

Pi: monthly precipitation in mm.

$\mathrm{P}$ : annual precipitation in $\mathrm{mm}$.

From the iso-erodent map, we deduce that the average erosivity for the Oued Haricha sub-basin is equal to 37.89 MJ*mm/ha/h.

\subsection{Soil-Erodibility Factor (K)}

The soil-erodibility factor $(\mathrm{K})$ represents the influence of soil properties and characteristics of the soil-profile on soil loss during storm events on upland areas [14]. Soil texture, organic matter, structure, and permeability determine the erodibility of a particular soil. $\mathrm{K}$ values for various soil types were estimated using the published soil erodibility nomograph [2] [15] [16] in different soil type already mapped [10] [11] [17]. The erodibility values in the study area range from 0.12 to $0.40 \mathrm{Mgh} / \mathrm{MJ} / \mathrm{mm}$. Table 1 shows that $44.47 \%$ of the soil series are characterized by low values $(\mathrm{K} \leq 0.2)$. Medium soil erodibility $(0.2$ to $0.3 \mathrm{Mgh} / \mathrm{MJ} / \mathrm{mm})$ represents $35.26 \%$ of the total area. The high values of $\mathrm{K}$ ( 0.3 to $0.4 \mathrm{Mgh} / \mathrm{MJ} / \mathrm{mm}$ ) represent $20.27 \%$. 
Table 1. K range interval and corresponding area.

\begin{tabular}{ccc}
\hline & \multicolumn{2}{c}{ Area } \\
\cline { 2 - 3 } $\mathrm{K}$ range & $\mathrm{Km}^{2}$ & Percent (\%) \\
\hline $0.1<\mathrm{K} \leq 0.2$ & 89.04 & 40.14 \\
$0.2<\mathrm{K} \leq 0.3$ & 9.61 & 4.33 \\
$0.3<\mathrm{K} \leq 0.4$ & 78.21 & 35.26 \\
Total & 44.96 & 20.27 \\
\hline
\end{tabular}

\subsection{Cover and Management Factor (C)}

The $\mathrm{C}$ factor represents the effect of plants, soil cover, below-ground biomass and soil-disturbing activities on soil erosion. It is used to reflect the effect of cropping and management practices on erosion rates. The $C$ values corresponding to each crop/vegetation condition were estimated from RUSLE guide tables [2] [5] for forests, matorrals and pastures and on the guide table of Cormary and Masson [18] for the types of culture, timing and crop rotations.

For this study, the $\mathrm{C}$ factor is determined from the update in the field of the crop/management map [11]. The results show that the values of the $\mathrm{C}$-factor are between 0.0 and 0.70 . They indicate that $22.54 \%$ of total area has a low and very low protection against erosion and $16.00 \%$ has good protection. The very good protection is dominated by land occupied by forests (52\%). Other areas outside of agriculture correspond to urban areas and bare land.

\subsection{Slope Length and Steepness Factor (LS)}

The effect of topography on erosion is accounted for by the LS factor. Erosion increases as slope length increase, and is considered by the slope length factor (L) [14] [19]. RUSLE uses one of four equations to compute LS values. The choice of LS equation is based on existing conditions including surface cover at the site. For this study, the LS factor is calculated from the formula of Wischmeier and Smith [2] in the out-of-box functionality of ArcMap [20] following the programmatic methods in Equations [21] [22]:

$$
\mathrm{LS}=(\mathrm{sl} / 22.13)^{\mathrm{m}} \cdot\left(0.065+0.045 \cdot \mathrm{S}+0.065 \cdot \mathrm{S}^{2}\right)
$$

where:

sl: is the slope length of the site (m).

$\mathrm{m}$ : is a coefficient related to the ratio of rill to inter-rill erosion presented in table below.

\begin{tabular}{ccccc}
\hline Slope & $\mathrm{P}<1$ & $1 \leq \mathrm{P}<3$ & $3 \leq \mathrm{P}<5$ & $\mathrm{P} \geq 5$ \\
\hline $\mathrm{m}$ & 0.2 & 0.3 & 0.4 & 0.5 \\
\hline
\end{tabular}

$\mathrm{S}$ : is the slope factor.

$\mathrm{S}=10.8 \sin \theta+0.03$, since the average angle of the slope $\theta$ (in degrees) of the sub-basin is less than $9 \%$ and the length $\geq 5 \mathrm{~m}$ [22].

Figure 4 shows that $65 \%$ of the total area of the sub-basin has LS values lower than 5 . The classes of LS upper than 15 are homogeneous across the sub-basin.

\subsection{Support Practice Factor (P)}

The P-factor describes the supporting effects of practices like contour farming, cross-slope farming, buffer strips, stripcropping, and terraces. It represents the ratio of soil loss from an area with supporting practices in place to 


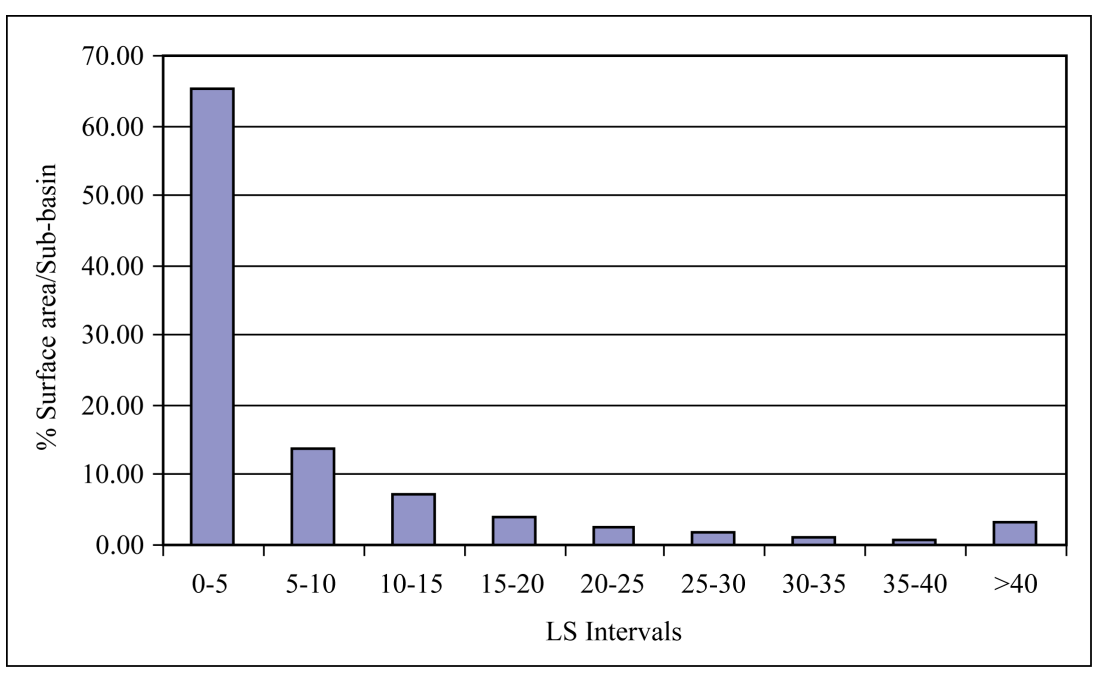

Figure 4. Distribution of the LS factor intervals in Oued Haricha sub-basin.

that from an identical area without any supporting practices. In the sub-basin of Oued Haricha, there are no support practices for soil conservation; the $\mathrm{P}$ factor is set to equal 1.

\section{Empirical Modelling}

The dataset used in this study consists of digitized maps, geo-referenced in the Moroccan projection system (Merchich Morocco, ellipsoid Clarke 1880) and projected in the Moroccan cartographic system (Lambert Conformal Conic, Zone-1). The geometric and cartographic parameters (river system, land use, climate and soil data) were extracted and listed in the GIS as vectors and raster layers (grid). Topographic parameters (slope map, contour map for each altitude, map exhibition, slopes map, slope lengths, etc.) were extracted from the digital elevation model. ArcGIS [20] was used to create relevant thematic layers and to generate a composite map for the revised (RUSLE) and modified (MUSLE) models of Wishmeier and Smith [2]. The results are presented as thematic maps.

After the text edit has been completed, the paper is ready for the template. Duplicate the template file by using the Save As command, and use the naming convention prescribed by your journal for the name of your paper. In this newly created file, highlight all of the contents and import your prepared text file. You are now ready to style your paper.

\subsection{Erosion on the Slopes by RUSLE Model}

The Revised Universal Soil Loss Equation (RUSLE) was examined as an improved method for estimating sheet and rill erosion at the Oued Haricha sub-basin. RUSLE calculates annual sheet and rill erosion from a hill slop by multiplying together several factors: the Soil-erodibility factor (K), Rainfall erosivity factor (R), Slope length and steepness factor (LS), Cover and management factor (C), and Support practice factor (P) [15] [16]. The annual average loss of long-term soil for Oued Haricha sub-basin is $62.72 \mathrm{t} / \mathrm{ha} / \mathrm{year}$. The spatial and statistical distribution of the RUSLE values (Figure 5, Figure 6) shows that the losses are located in the range of less than 50 tons/ha/year and constitute over $60 \%$ of the total area. Only $18 \%$ of the territory is subject to excessive erosion (over $100 \mathrm{t} / \mathrm{ha} /$ year), exceeding Wischmeier tolerance levels.

\subsection{Erosion at the Outlet of the Sub-Basin by MUSLE Model}

Erosion at the outlet of the Oued Haricha sub-basin is evaluated from MUSLE model (Modified Universal Soil Loss Equation) of Williams and Berndt [23]. It involves the peak flow and total volume of water runoff to predict soil erosion for an event of erosion of the water. The equation, corrected by Renard et al., [16] is as follows:

$$
\mathrm{A}=\mathrm{C} 1(\mathrm{Vr} . \mathrm{Qp}) \text { 0.65.K.LS.C.P }
$$




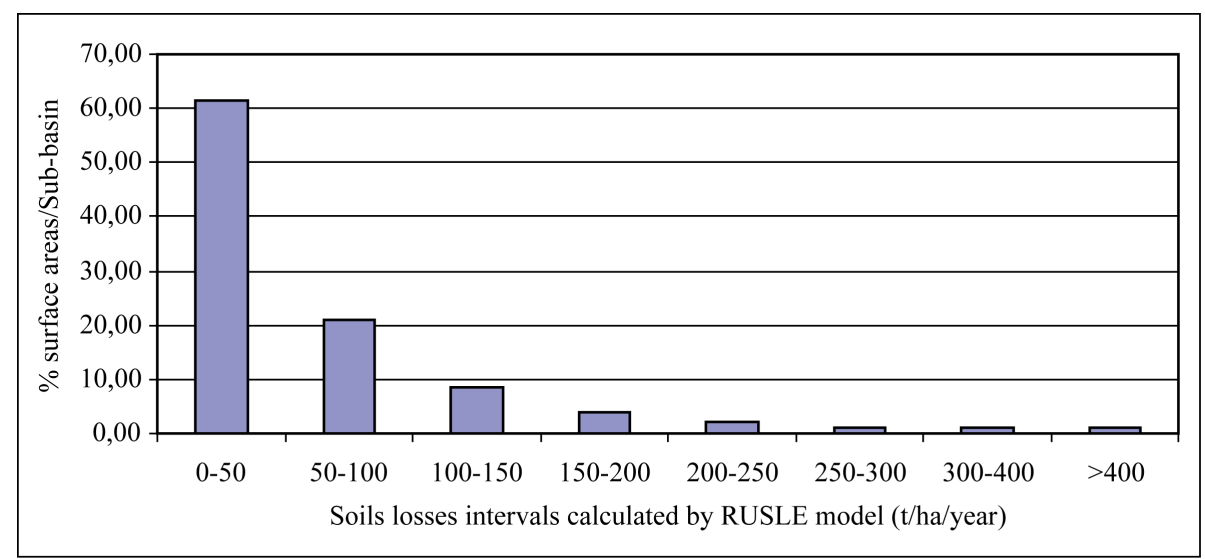

Figure 5. Distribution of soil loss by RUSLE model.

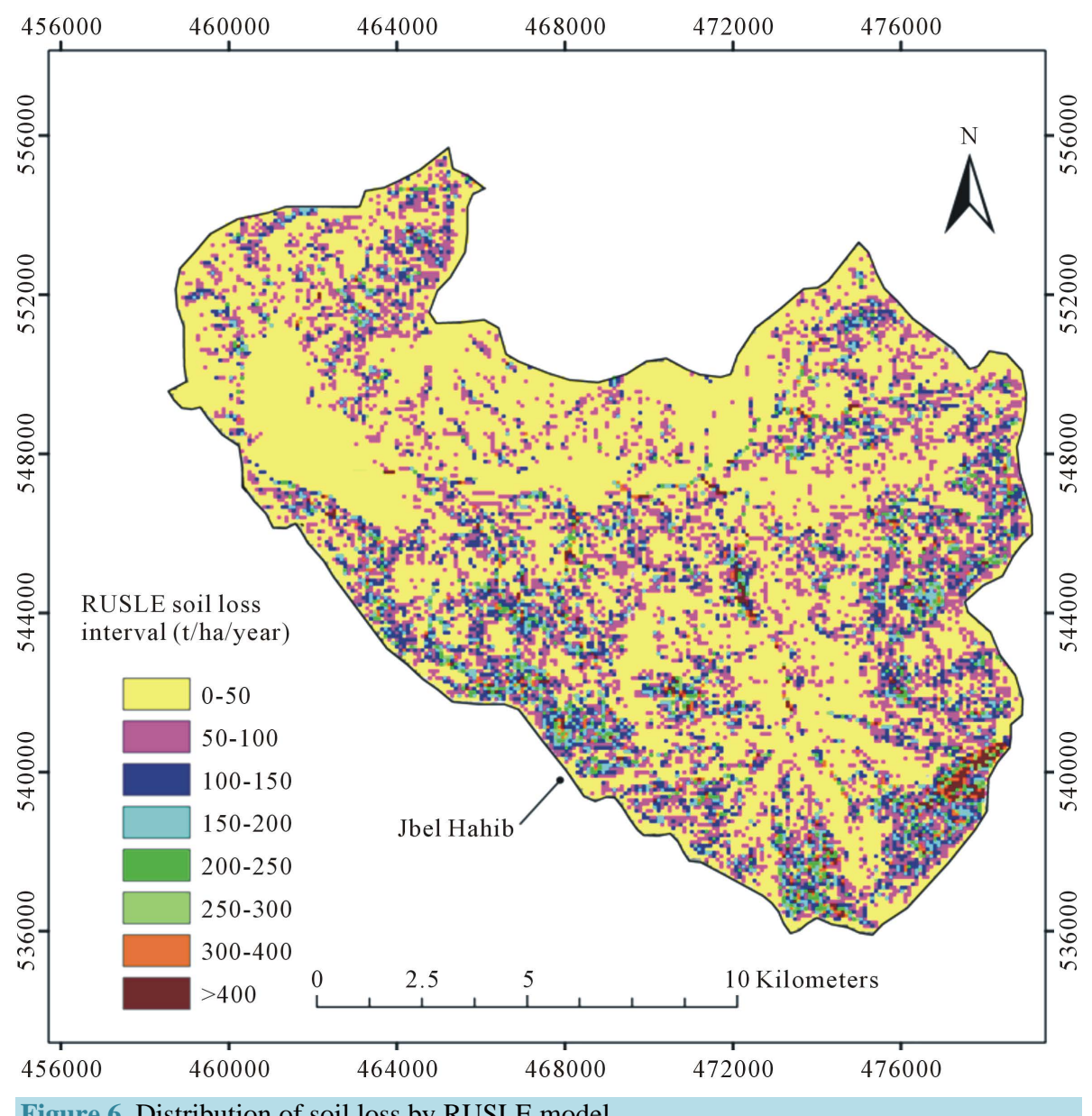

Figure 6. Distribution of soil loss by RUSLE model.

where, A is sediment yield produced by sub-basin in t/year, C1: Conversion factor equal to 9.05 or 11.8 in International Unit System. In Morocco, C1 = 9.05. Qp is peak flow rate in $\mathrm{m}^{3} / \mathrm{s}$. $\mathrm{Vr}$ is volume of runoff in $\mathrm{m}^{3} / \mathrm{year}$, determined from hydrometric stations. K, LS, C and P are respectively, erodibility, topography, crop management and soil erosion control practice factors (all dimensionless).

The average annual losses at the outlet of the Oued Haricha sub-basin are 221,468 tons. The spatial distribution of losses (Figure 7, Figure 8) shows that 22\% of the sub-basin area generates low levels of sediment (less than 50,000 t/year). These are the raised lands that produce larger amounts of sediments (over 100,000 t/year). 


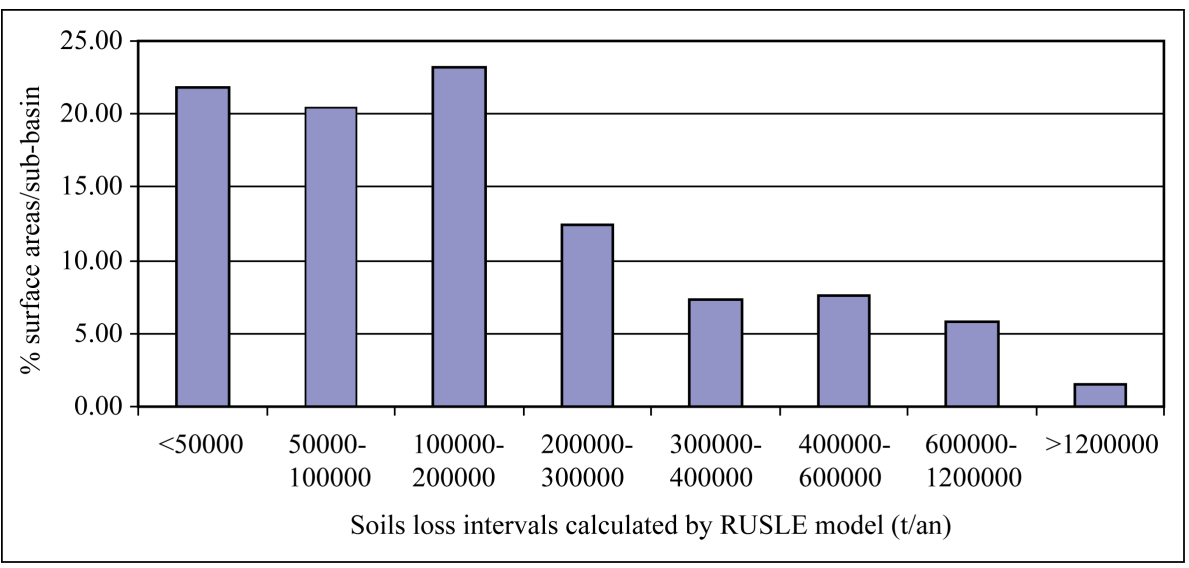

Figure 7. Distribution of soil loss by MUSLE model.

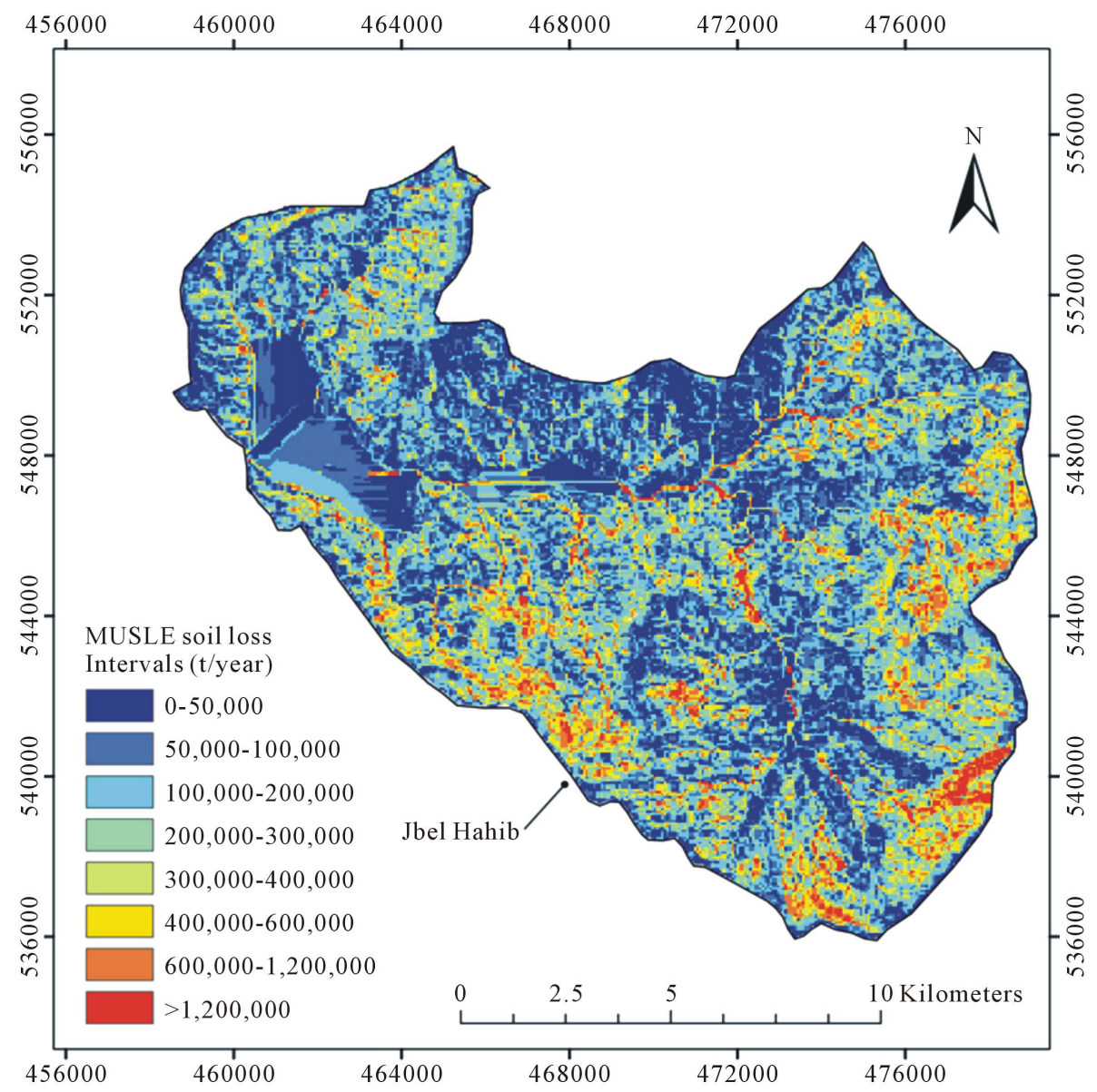

Figure 8. Loss map by Williams model.

\subsection{Erosion Caused by the Hydrographic Network}

The estimation of the contribution of the river system in the production of sediments occurs after subtraction of values calculated from MUSLE model to that derived from RUSLE model, since linear erosion is assumed dominant compared to other forms of erosion. The results show that the loss rates due to linear erosion are at the average of $82,652 \mathrm{t} / \mathrm{year}$. These losses, due to hydrographic network, constitutes $20.33 \%$ of the total losses (Figure 9). Thus, the losses on the slopes outweigh the losses due to the river system. 


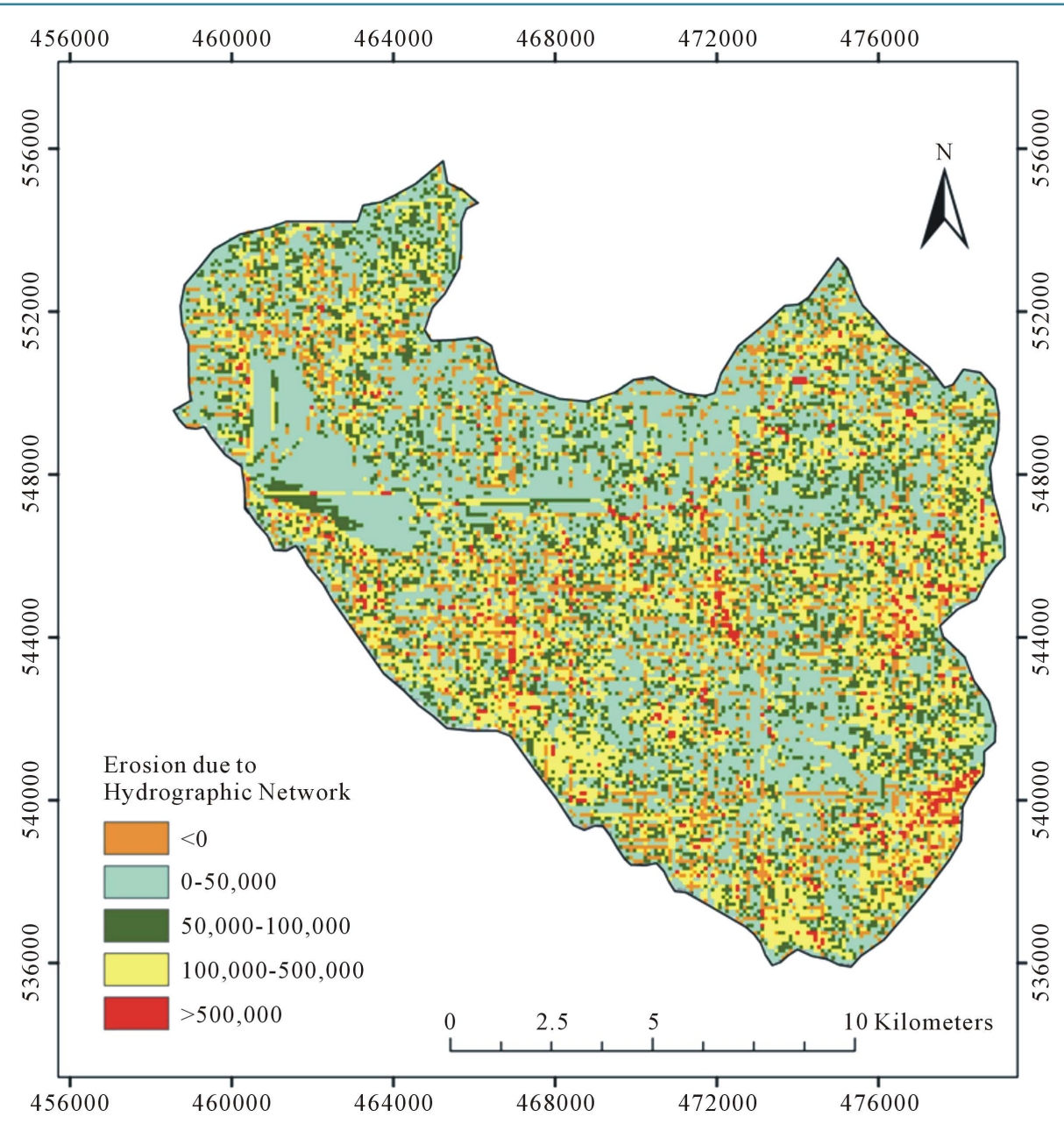

Figure 9. Map of losses related to Hydrographic Network.

\subsection{Sedimentation Model}

The sedimentation model (deposition) is based on the results of the RUSLE model to calculate the balance sheet of the erosion in each individual parcel. It uses homogeneous polygons resulting from the calculation of the RUSLE model to assess the net movement of the soil (erosion or deposition) in parcels or sub-basins [24] [25]. It also requires the digital terrain model (DTM) and represents an extension of the incorporation of RUSLE in a GIS environment [24].

Application of sedimentation model for in the Oued Haricha sub-basin helped to clarify the rates of soil loss and sedimentation (Figure 10). Calculation results of the net annual soil loss show that:

- Areas with losses from 0.0 to 50 tonnes/ha/year are concentrated at the outlet of the sub-basin in an area of 3023 ha (13.63\% of the total area);

- Areas with average loss between 100 and 200 t/ha/year constitutes approximately 25\% of total surface (or 5210.39 ha);

- Areas with high losses (200 to 400 t/ha/year) occupy regions with an average slope over an surface area of 5210.39 ha (23.49\% of the total area);

- The regions of very high losses (over $400 \mathrm{t} / \mathrm{ha} / \mathrm{year}$ ) dominate especially on the upstream reliefs southeast sub-basin. They correspond to areas of high gradient and occupy 14.7\% of the total area (3261.58 ha of total area);

- The regions of low slope correspond to areas where dominate sedimentation (or deposition) on erosion. These areas occupy the center of the sub-basin in the edges of the main rivers in a surface area of 2022.55 ha (9.12\% of the total area). 


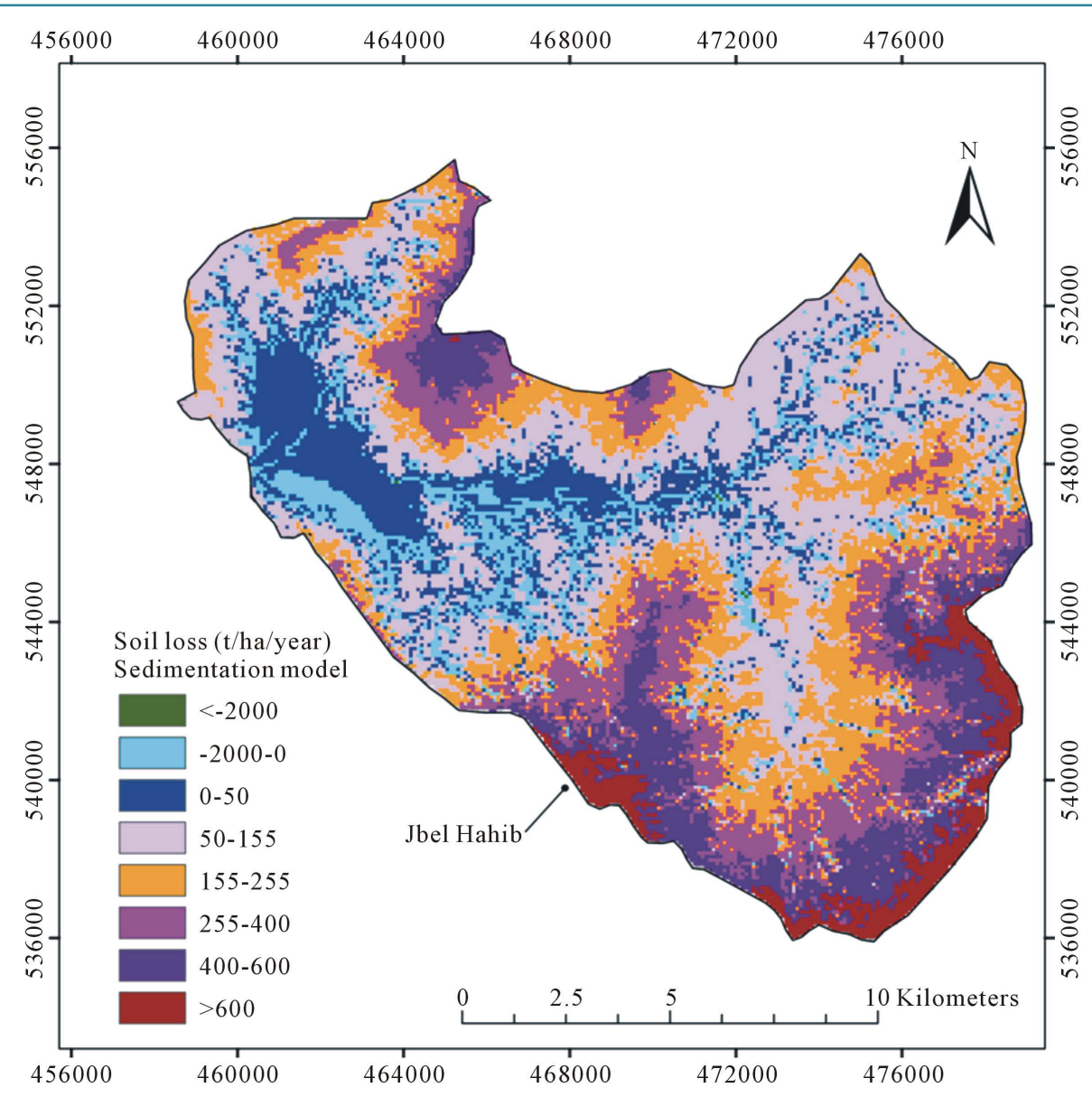

Figure 10. Map of soil losses by Deposition model.

\section{Discussion and Conclusion}

This study evaluates the erosion based on changes in the characteristics of precipitation and runoff, the properties of land use and practices in a mountainous area of the western Rif (NW Morocco).

The Rainfall erosivity factor (R) calculated for the sub-basin of the Oued Haricha is equal to $37.89 \mathrm{MJ} * \mathrm{~mm} /$ $\mathrm{ha} / \mathrm{h}$. This value is close to the values determined in central and western Rif and the Rif foreland. In the Central Rif, R index ranges from 43 to 87.56 in the watershed of Oued Lben [26] and is estimated to 51 to 194 in Ouergha Valley [27]. In the eastern foreland of the Rif chain, this index is estimated at 56.3 in the watershed of Oued Tleta [25], and ranges from 40 to $50 \mathrm{~mm} * \mathrm{MJ} / \mathrm{ha} / \mathrm{h}$ in the watershed of Oued Boussouab [28]. In the western Rif, Tahiri et al. [9] calculated a value of $\mathrm{R}=54.75 \mathrm{MJ} * \mathrm{~mm} / \mathrm{ha} / \mathrm{h}$ in the sub-basin of Oued Sania.

This study shows that erosion is slightly constrained by the vegetal cover. The spatial distribution of the vegetation cover index (C) shows that $22.54 \%$ of the surface has low protection against erosion. The very good protection is dominated by land occupied by forests (52\%).

The distribution map of the soil-erodibility factor (K) shows that over $35 \%$ of the sub-basin area has an average erodibility. This is explained by the abundance of vertisols and lower developed soils, usually from the alteration of the bedrock constituted by marl and flysch very permeable and easily erodible. Good protection is visible on $44 \%$ of the total area.

The results of LS calculation factor of the sub-basin of Oued Haricha show that downstream and center reliefs constitute $65 \%$ of the total area where LS values are smaller to 5 . They exhibit flattened morphology and show relatively low potential role of this index in the quantification of erosion.

The crossing of synthetic maps of different factors using a GIS enabled an assessment and quantification of erosion. The actual erosion by the RUSLE method is $62.72 \mathrm{t} / \mathrm{ha} / \mathrm{year}$ with a medium level of risk. These results show that the values recorded in the sub-basin of Oued Haricha and the results of previous studies in the Prerif 
[25] [29]-[32] and the Western Rif [9] are much higher than the tolerance levels (RUSLE value $>11$ t/ha/year). Soil losses lower than $50 \mathrm{t} / \mathrm{ha} /$ year are more than $60 \%$ of the total area. This shows the seriousness of the specific degradation due to the type of land use, lithology, topography and especially to climate changes that promote soil erosion. Last studies show that climate is marked in northern Morocco by a predominantly negative precipitation evolution and a general tendency toward warmer and drier conditions [33]. Precipitation is likely to decrease between 10 and $20 \%$, while temperatures are likely to rise between $2^{\circ} \mathrm{C}$ and $3^{\circ} \mathrm{C}$ by 2050 [34] [35].

The total loss at the outlet by the MUSLE methods is averaged to 221,468 t/year. Low rates (less than 50,000 $\mathrm{t} /$ year) are $22 \%$ of the area of the sub-basin and dominate the downstream reliefs and rivers. These are the raised lands that produce larger amounts of sediments (over 100,000 t/year). This highlighted the risk of these losses in siltation of the April 9, 1947 dam.

Soil losses due to the hydrographic network or linear erosion, are about $20.33 \%$, confirming that the losses on the slopes, or sheet erosion and rill outweigh the losses due to the river system. The values calculated after subtracting MUSLE data and RUSLE using a GIS can calculate the average annual loss rate of 82,652 t/year.

Application of Deposition module helped to clarify the rate of loss of soil and sedimentation. The regions of very high losses (greater than 200,000 t/ha/year) occupy the middle slope areas and contribute to siltation of the April 9, 1947 dam. The regions of low slope correspond to areas dominated by sedimentation (or deposition) on erosion. These areas occupy the center of the sub-basin on the edges of major rivers and constitute $9.12 \%$ of the total area.

This study has identified various areas at risk of erosion and quantified the deposition. Erosion causes damage to farmland but also degrades water quality and sediment movement. To address the risk, control ways must be within the emitting runoff regions and sensitive areas accumulating precipitation. This is to reduce surface runoff and training detachments and transport capacity of runoff by limiting its speed and concentration.

\section{References}

[1] Walling, D.E. (2009) The Impact of Global Change on Erosion and Sediment Transport by Rivers: Current Progress and Future Challenges. The United Nations World Water Development Report 3 Water in a Changing World, International Sediment Initiative of UNESCO-IHP.

[2] Wischmeier, W.H. and Smith, D.D. (1978) Predicting Rainfall Erosion Losses-A Guide to Conservation Planning. USDA Handbook No. 537, U.S. Department of Agriculture in Cooperation with Purdue Agricultural Experiment Station.

[3] Flanagan, D.C. and Nearing, M.A. (1995) USDA Water Erosion Prediction Project: Hillslope Profile and Watershed Model Documentation. NSERL Report No. 10, USDA-ARS National Soil Erosion Research Laboratory, West Lafayette, IN 47907-1194.

[4] Arnold, J.G., Srinivasan, R., Muttiah, R.S. and Williams, J.R. (1998) Large Area Hydrologic Modeling and Assessment Part I: Model Development. Journal of American Water Resources Association, 34, 73-89. http://dx.doi.org/10.1111/j.1752-1688.1998.tb05961.x

[5] Morgan, R.P.C., Quinton, J.N., Smith, R.E., Govers, G., Poesen, J.W.A., Auerswald, K., Chisci, G., Torri, D. and Styczen, M.E. (1998) The European Soil Erosion Model (EUROSEM): A Dynamic Approach for Predicting Sediment Transport from Fields and Small Catchments. Earth Surface Processes and Landforms, 23, 527-544. http://dx.doi.org/10.1002/(SICI)1096-9837(199806)23:6<527::AID-ESP868>3.0.CO;2-5

[6] Tahiri, M. (2014) Contribution de l'outil de l'observation de la Terre à l'analyse du milieu environnemental du bassin de Tahaddart (Rif nord occidental, Maroc). Doctorat, Hassan II University of Casablanca, Morocco, 256 p.

[7] Tahiri, M., Achab, M., Emran, A., Tahiri, A., Hakdaoui, M. and El Hadi H. (2014) Lithology Data Contribution in Hydrographic Network Distribution Using Remote Sensing and GIS: Case of the Tahaddart Basin, Northwestern Rif, Morocco. International Journal of Advanced Research, 2, 380-391.

[8] Tahiri, M., Hakdaoui, M., Emran, A., Achab, M., El Hadi, H. and et Tahiri, A. (2014) Contributions du SIG et de la Télédétection à la corrélation entre le NDVI et la pluviométrie pour l'étude de la variabilité climatique dans le bassin de Tahaddart (Rif, Maroc). European Journal of Scientific Research, 122, 253-274.

[9] Tahiri, M., Tabyaoui, H., El Hammichi, F., Tahiri, A. and El Haddi, H. (2014) Evaluation et Quantification de l'Erosion et la Sédimentation à Partir des Modèles RUSLE, MUSLE et Déposition Intégrés dans un SIG. Application au Sous-Bassin de l'Oued Sania (Bassin de Tahaddart, Rif nord occidental, Maroc). European Journal of Scientific Research, 125, 157-178.

[10] Billaux, P. and Bryssine, G. (1967) Les sols du Maroc. In : Congrès de pédologie méditerranéenne: Excursion au Maroc. Cahiers de la Recherche Agronomique, 1, 59-101. 
[11] El Gharbaoui, A. (1981) La terre et l'homme dans la péninsule tingitane: Etude sur l'homme et le milieu naturel dans le Rif Occidental. Travaux de l'Institut Scientifique, série Géologie Géographie Physique, 15, 1-439.

[12] CPCS, Commission de Pédologie et de Cartographie des Sols (1967) Classification des sols. Laboratoire de Géologie et de Pédologie, Ecole Nationale Supérieure d’Agronomie, Grognon, France, 87 p.

[13] Arnoldus, H.M.J. (1980) An Approximation of the Rainfall Factor in the Universal Soil Loss Equation. In: De Boodt, M. and Gabriels, D., Eds., Assessment of Erosion. FAO Land and Water Development Division, Wiley \& Sons, Chichester, 127-132.

[14] Fox, H.R., Moore, H.M. and Newell Price, J.P. (1997) Soil Erosion and Reservoir Sedimentation in the High Atlas Mountains, Southern Morocco. In: Walling, D.E. and Probst, J.L., Eds., Human Impact on Erosion and Sedimentation, IAHS Publ. No 245, 233-240.

[15] Renard, K.G., Foster, G.R., Weesies, G.A. and Porter, J.P. (1991) RUSLE: Revised Universal Soil Loss Equation. Journal of Soil and Water Conservation, 46, 30-33.

[16] Renard, K.G., Foster, G.R., Weesies, G.A., McCool, D.K. and Yoder, D.C. (1997) Predicting Soil Erosion by Water: A Guide to Conservation Planning with the Revised Universal Soil Loss Equation (RUSLE). US Department of Agriculture, Washington DC.

[17] Osrirhi, A., El Oumri, M., Moussadek, R., Moatamid, Z., Ambri, A. and Goebel, W. (2007) Vocation agricole des terres de la zone d'Oujda -Rapport et cartes. Rapport-Institut National de la Recherche Agronomique. http://www.inra.org.ma/environ/docs/cvat/oujda/oujda.pdf

[18] Cormary, Y. and Masson, J. (1963) Application à un projet type de la formule de perte de sols de Wischmeier. Etude de conservation des eaux et du sol au Centre de recherches du génie rural de Tunisie, 26 p.

[19] McCool, D.K., Foster, G.R., Mutchler, C.K. and Meyer, L.D. (1989) Revised Slope Length Factor the Universal Soil Loss Equation. Transactions of the American Society of Agricultural Engineers, 32, 1571-1576. http://dx.doi.org/10.13031/2013.31192

[20] ESRI (1999) ArcView GIS 3.2. Environmental Systems Research Institute, Inc., Redlands.

[21] Van Remortel, R., Hamilton, M. and Hickey, R. (2001) Estimating the LS Factor for RUSLE through Iterative Slope Length Processing of Digital Elevation Data. Cartography, 30, 27-35. http://dx.doi.org/10.1080/00690805.2001.9714133

[22] Renard, K.G., Foster, G.R., Weesies, G.A., McCool, D.K. and Yoder, D.C. (1997) Predicting Soil Erosion by Water: A Guide to Conservation Planning with the Revised Universal Soil Loss Equation. US Government Printing Office, Washington DC.

[23] Williams, J.R. and Berndt, H.D. (1976) Determining the Universal Soil Loss Equation's Length-Slop Factor for Watersheds. Proceedings of the National Soil Erosion Conference, West Lafayette, 25-26 May 1976, 217-225.

[24] Lewis, L.A., Verstraeten, G. and Zhu, H. (2005) RUSLE Applied in a GIS Framework: Calculating the LS Factor and Deriving Homogeneous Patches for Estimating Soil Loss. International Journal of Geographical Information Science, 19, 809-829. http://dx.doi.org/10.1080/13658810500105705

[25] El Garouani, A., Tribak, A. and Abahrour, M. (2010) Assessment the Effects of Land-Use Cover Changes on Regional Soil Loss Susceptibility Using RUSLE Model and Remote Sensing Data. Red Books, International Association of Hydrological Sciences Publication, No. 340, 343-349.

[26] Rahhou, M. (1999) L’érosion dans le Prérif central, zone interfluviale Leben-Sebou-Ouergha, un prolongement de l'évolution naturel, une production sociale. State thesis, Mohammed V University of Rabat, Morocco.

[27] Le Landais, F. and Fabre, G. (1975) Plan d'aménagement anti-érosif du bassin versant de l’oued Ouergha en amont du barrage El Ouahda. Rapport inédit, Administration des Eaux et Forêts et de la Conservation des Sols.

[28] Sadiki, A., Bouhlassa, S., Auajjar, J., Faleh, A. and Macaire, J.J. (2004) Utilisation d'un SIG pour l'évaluation et la cartographie des risques d'érosion par l'Equation universelle des pertes en sol dans le Rif oriental (Maroc): Cas du bassin versant de l’oued Boussouab. Bulletin de l’Institut Scientifique, Rabat, section Sciences de la Terre, No. 26, 6979.

[29] Heusch, B. (1970) L'érosion dans le Prérif: Une étude quantitative de l'érosion hydraulique dans les collines marneuses du Prérif occidental. Annales des recherches forestières, 12, 9-176.

[30] Fora, A. (1995) Modélisation spatiale de l'érosion hydrique dans un bassin versant du Rif marocain: Validation de l'approche géomatique par la sédimentologie, les traceurs radioactifs et la susceptibilité magnétique des sédiments. $\mathrm{PhD}$, Université de Sherbrooke, Québec.

[31] Siteri, H., Aït Brahim, L., Sossey, A.F., Al Hamdouni, I., El Hatimi, N., Labraimi, M., Ammar, A., Baghdad, B. and Tahri, M. (2003) Intégration du modèle USLE dans un SIG pour la détermination de la dégradation spécifique des sols dans le Rif septentrional (cas du bassin versant de l'oued Nakhla). Travaux de l'Institut Scientifique de Rabat, Série 
Géologie et Géographie Physique, 21, 241-276.

[32] Laaroussi, O. (2014) Etude de l'érosion et de la déposition des sols à l'échelle du bassin versant de l'Oued El Maleh (Fès, Maroc) par l'utilisation conjointe de la télédétection, du SIG et des techniques de mesures sur le terrain. Doctorat, Faculty of Sciences and Technology, Fès, Morocco, 141 p.

[33] Schilling, J., Freier, K.P., Hertige, E. and Scheffrana, J. (2012) Climate Change, Vulnerability and Adaptation in North Africa with Focus on Morocco. Agriculture, Ecosystems and Environment, 156, 12-26. http://dx.doi.org/10.1016/j.agee.2012.04.021

[34] Gerstengarbe, F.W. and Werner, P.C. (2007) Der rezente Klimawandel. In: Endlicher, W. and Gerstengarbe, F.W., Eds., Der Klimawandel_Einblicke, Rückblicke und Ausblicke, Humboldt University, Berlin, 34-43.

[35] Born, K., Fink, A. and Paeth, H. (2008) Dry and Wet Periods in the Northwestern Maghreb for Present Day and Future Climate Conditions. Meterologische Zeitschrift, 17, 533-551. http://dx.doi.org/10.1127/0941-2948/2008/0313 